Jurnal Interpretasi Hukum | ISSN: 2746-5047

Vol. 2, No. 3-Desember 2021, Hal. 567-572| Tersedia online di

https://www.ejournal.warmadewa.ac.id/index.php/juinhum

DOI: https://doi.org/10.22225/juinhum.2.3.4138.567-572

\title{
SANKSI PIDANA BAGI KEGIATAN MEREVIEW SUATU PRODUK USAHA DI MEDIA SOSIAL TANPA IZIN
}

\author{
Bagus Andika Artha Surya, Anak Agung Sagung Laksmi Dewi, Luh Putu Suryani \\ Fakultas Hukum, Universitas Warmadewa, Denpasar-Bali, Indonesia \\ andika.artha12@gmail.com, laksmidewi2909@gmail.com, putusuryani099@gmail.com
}

\begin{abstract}
Abstrak
Dalam persaingan dunia usaha salah satu cara yang efektif sebagai sarana promosi adalah mereview atau mengulas produk merupakan kegiatan yang dilakukan oleh konsumen untuk memberikan kesan dan pandangannya tentang suatu produk agar menjadi pertimbangan bagi konsumen lain sebelum membeli produk tersebut, namun terdapat dampak negatif dari kegiatan ini yakni apabila disalahgunakan oleh oknum yang tidak bertanggung jawab maka yang terjadi adalah oknum tersebut memberikan citra yang kurang bagus pada pelaku usaha karna kegiatan tersebut dan mempengaruhi konsumen yang akan membeli produk tersebut. Tujuan penelitian ini guna menganalisa sanksi pidana yang dapat dikenakan dari kegiatan review atau mengulas suatu produk yang memiliki hak cipta tanpa izin dari pelaku usaha. Penelitian ini mengaplikasikan metode normatif dengan pendekatan perundang-undangan. Teknik pengumpulan data dilakukan dengan cara meneliti bahan pustaka yang ada. Adapun sumber hukum yang digunakan terbagi dua yaitu sumber hukum primer dan sekunder yang kemudian dianalisis dengan metode interpretasi hukum, argumentasi hukum, dan konstruksi hukum. Hasil penelitian mengukapkan bahwa kegiatan mereview suatu produk juga diatur melalui pasal 27 ayat (3) undangundang nomor 19 tahun 2016 tentang perubahan atas undang-undang nomor 11 tahun 2008 tentang informasi dan transaksi elektronik yang bertujuan untuk melindungi brand dari pencemaran nama baik.
\end{abstract}

Kata Kunci: Konsumen, Produk, Sanksi Pidana

\begin{abstract}
In the competitive world of business, one effective way as a means of promotion is reviewing or reviewing products, which are activities carried out by consumers to give their impressions and views about a product so that it becomes a consideration for other consumers before buying the product, but there are negative impacts from this activity, namely if it is misused by irresponsible persons, what happens is that the person gives a bad image to business actors because of these activities and affects consumers who will buy the product. The purpose of this study is to analyze the sanctions that can be imposed from reviewing or reviewing a product that has copyright without permission from business actors. This study applies a normative method with a statutory approach. Data collection techniques were carried out by examining existing library materials. The sources of law used are divided into two, namely primary and secondary sources of law which are then analyzed by methods of legal interpretation, legal argumentation, and legal construction. The results of the study reveal that the activity of reviewing a product is also regulated through Article 27 paragraph (3) of Law 19 of 2016 concerning amendments to Law Number 11 of 2008 concerning information and electronic transactions aimed at protecting brands from good name numbers.
\end{abstract}

Keywords: Consumers, Products, Criminal Sanctions

\section{PENDAhUluan}

Dewasa ini ditengah ketatnya persaingan globalisasi yang terjadi diseluruh dunia, perdagangan di Indonesia mengalami perkembangan yang cukup pesat. Perkembangan tersebut menyebabkan munculnya berbagai jenis barang dan/atau jasa yang bisa dimanfaatkan konsumen. Biasanya, konsumen cenderung memilih barang dan/atau jasa yang kualitasnya sudah teruji dan terjamin yang telah diulas sebelumnya. Ulasan produk adalah tulisan yang ditulis konsumen pada kolom yang sudah disiapkan oleh e-commerce yang mencerminkan kualitas barang yang sebenarnya, seperti masalah warna, spesifikasi tidak konsisten, masalah penggunaan, atau kualitas tinggi, dan pengalaman yang baik (Ilmiyah \& Krishernawan, 2020). Kualitas berkaitan dengan review atau ulasan suatu produk di mata konsumen. Review atau ulasan yang baik akan memberi nilai tambahan bagi produk tersebut menjadi pilihan konsumen di pasaran, sebaliknya jika review atau ulasan suatu produk buruk itu akan 
membuat konsumen enggan memilih produk tersebut karena tidak mau menanggung kerugian akibat salah pilih produk sehingga konsumen akan beralih memilih produk yang memiliki review atau ulasan yang baik. Dasar hukum perlindungan hukum mereview atau mengulas produk di Indonesia adalah Pasal 28E Undang-undang Negara Republik Indonesia Tahun 1945, Pasal 310 dan Pasal 311 Kitab Undang-undang Hukum Pidana dan Undang-undang Nomor 19 Tahun 2016 tentang Informasi dan Transaksi Elektronik.

Sejalan dengan kemajuan teknologi, perkembangan di bidang bisnis juga semakin ketat banyak nya jumlah pelaku usaha yang tidak sebanding dengan jumlah konsumen menyebabkan pelaku usaha harus berusaha keras mempromosikan produk yang dimilikinya agar diminati oleh konsumen dengan menambah fitur review atau ulasan produk, dan konsumen juga sebenernya sangat dibantu dengan adanya fitur ini karena bisa memberi bayangan akan seperti apa dan bagaimana kualitas dari produk yang ditawarkan. Tetapi banyak kita lihat oknum oknum yang tidak bertanggung jawab yang merusak citra dari pelaku usaha dengan menyebarkan review palsu atau fitnah untuk menjatuhkan nama baik pelaku usaha dimata konsumen (Atmadja, I Dewa Gede Budiartha, 2019).

Saat ini terjadi fenomena dimana media sosial digunakan untuk menyebarkan berita bohong atau hoax sehingga beberapa kasus mengenai penyebaran berita hoax berurusan dengan aparat penegak hukum (Hadiyati et al., 2018). Informasi atau berita (pesan) hoax diproduksi kemudian digunakan oleh pengguna internet dengan mengirimkan informasi tersebut ke pengguna lainnya (penerima pesan). Dalam proses ini antara pengirim maupun penerima dapat saling bertukar peran sebaliknya (Juditha, 2018). Lebih lanjut, Rizaldi (2015) berpendapat bahwa saat ini, setiap orang juga dapat dijerat dengan ancaman pidana atas perbuatan penghinaan dan/atau pencemaran nama baik di internet. Khusus untuk pengguna internet, ancaman pidana dirumuskan melalui Pasal 27 ayat (3) jo Pasal 45 UU ITE. Melalui ketentuan ini, pengguna internet juga dapat dikenakan upaya paksa mengingat ancaman pidananya maksimal 5 tahun penjara. Dari fenomena tersebut maka dilakukannya penelitian yang bertujuan untuk menganalisa menganalisa sanksi pidana yang dapat dikenakan dari kegiatan review atau mengulas suatu produk yang memiliki hak cipta tanpa izin dari pelaku dengan tujuan menyebarkan review palsu atau hoax untuk menjatuhkan nama baik pelaku usaha dimata konsumen.

\section{METODE PENELITIAN}

Di dalam melakukan penelitian ini penulis memakai metode penelitian hukum normative dengan pendekatan perundang-undangan yang berfokus pada pembahasan hukum tertulis terdiri dari berbagai macam sumber hukum. Teknik pengumpulan data dilakukan dengan cara meneliti bahan pustaka yang ada yang berupa sumber hukum primer dan sekunder. Sumber hukum primer terdiri dari undang undang, peraturan pemerintah, juga sumber hukum sekunder yakni jurnal, literatur, buku, dan karya tulis ilmiah lainnya. Selanjutnya setelah bahan hukum yang terkait dengan mereview atau mengulas produk bahan hukum ini dianalisis dengan metode interpretasi hukum, argumentasi hukum, dan konstruksi hukum (Fajar \& Achmad, 2010).

\section{HASIL DAN PEMBAHASAN}

\section{Sanksi Pidana yang Dapat dikenakan Dari Kegiatan Review atau Mengulas Suatu Produk yang Memiliki Hak Cipta Tanpa Izin Dari Pelaku Usaha}

Sebagai makhluk social manusia dalam menjalankan aktivitasnya selalu bergantung dengan manusia lainnya yang menimbulkan ikatan dengan tujuan yang berbeda beda. Di jaman sekarang yang serba canggih ini manusia dituntut untuk selalu bisa beradptasi dengan perubahan, perubahan yang dimaksud adalah kondisi dimana kita harus siap dengan berkembang pesatnya ilmu pengetahuan dan teknologi yang berakibat berubahnya kondisi social yang ada dimasyarakat. Tidak sedikit individu yang bersaing dengan individu lain agar bisa memenuhi kebutuhannya melalui kemampuan menciptakan sesuatu hal yang kreatif, inovatif, dan juga bermanfaat bagi masyarakat luas,

Mengutip pernyataan Liu dan Tsai dalam bukunya, (Sutedi, 2009) kemajuan teknologi dari internet menyebabkan perubahan gaya hidup konsumen. Saat ini terjadi perubahan yang signifkan yakni perubahan cara berbelanja suatu produk. Apabila dulu seseorang ingin berbelanja suatu produk maka biasanya harus pergi dulu ke offline store, tetapi yang terjadi sekarang malah sebaliknya 
konsumen cenderung berbelanja suatu produk secara online melalui media platform e commerce. Hal ini dikarenakan karena berbagai faktor diantaranya:

1. Lebih praktis : Berbelanja secara online bukan hanya menghemat waktu tapi juga tenaga, kita hanya perlu menggunakan smartphone untuk mengakses belanja apapun yang kita mau dan dimanapun kita berada.

2. Lebih Hemat : Saat ini banyak dari platform e-commerce atau marketplace yang menjual kebutuhan sehari hari mengadakan promosi baik itu berupa potongan harga atau diskon, atau promo lainnya yang bertujuan menarik konsumen untuk berbelanja online.

3. Lebih Waspada : Dalam berbelanja secara online di e-commerce, kita tidak bisa melihat secara langsung produk yang dijual melainkan hanya dapat melihat produk berupa gambar atau video. Tentu hal ini salah satu resiko dari berbelanja online tetapi di marketplace atau ecommerce biasanya kita dapat melihat review atau ulasan tentang produk yang dijual yang dapat dijadikan bahan pertimbangan sebelum membeli produk.

Transaksi jual beli di dalam platform online seperti market place atau e-commerce saat ini banyak digemari oleh masyarakat dari segala usia, dari anak anak hingga orang dewasa terbiasa berbelanja secara online. Hal ini berpengaruh pada tingkat lapangan pekerjaan dikarenakan market place ini menjadi tempat penghubung pembeli, penjual, dan pihak lain. Pembeli dapat melakukan transkasi belanja dimana saja, kapan saja, dan membeli barang apapun yang diinginkan melaui smartphone. Sementara itu penjual juga dapat menjual barang dagangannya di market place secara online tidak harus membuka offline store tapi bisa berjualan hanya dari rumah, dan bagi pihak lain seperti penyedia platform dapat membuka usahanya sekaligus menambah lapangan pekerjaan yang ada dimasyarakat serta bagi pihak lain seperti driver juga bisa mendapat pekerjaan untuk menghidupi keluarganya dengan menjadi driver.

Banyak hal yang melatar belakangi perubahan perilaku konsumen dari belanja secara offline menjadi belanja menggunakan metode online salah satunya yakni berdasarkan pada kemudahan berbelanja yang ditawarkan oleh system belanja online. Dengan hanya bermodalkan smartphone dan jaringan internet seluler kita dapat mengakses belanja secara online dari manapun dan dalam kondisi apapun, hal ini menjadi nilai tambah yang diberikan system belanja online dari pada berbelanja secara offline. Namun dibalik semua manfaat yang ditawarkan oleh system belanja online, tentu juga ada faktor yang menyebabkan konsumen enggan berbelanja secara online diantaranya:

1. Keamanan Produk: Dalam bertranksasi belanja secara online konsumen tidak dapat melihat produk secara real time melainkan hanya dapat melihat produk melalui media foto atau video yang diberikan oleh penjual, berdasarkan hal tersebut lah konsumen sering kali merasa ragu untuk berbelanja secara online karna tidak bisa melihat fisik dari produk yang dijual.

2. Keamanan Pembayaran : Selain produk yang tidak bisa dilihat biasanya untuk metode pembayaran produk menggunakan cashless transfer atau pembayaran tanpa uang tunai dengan transfer antar bank, masalah yang sering terjadi yaitu Ketika konsumen sudah mentransfer dana kepada penjual tetapi penjual tidak mengirim produk atau mengirim produk yang tidak sesuai dengan pesanan penjual.

3. Keamanan Data Pribadi : Dengan berkembangnya teknologi dan informasi saat ini maka berkembang juga berbagai jenis kejahatan yang mengancam individu termasuk dalam hal internet dan siber. Banyak kita lihat data pribadi kita yang terdaftar dalam aplikasi e commerce diduga bocor untuk diperjual belikan secara illegal, hal ini tentu sangat merugikan privasi konsumen.

Ketiga faktor diatas memunculkan persepsi terhadap resiko kepada konsumen, persepsi negative atau pandangan buruk merupakan pemikiran liar atas berbagai kemungkinan buruk yang akan terjadi akibat dari adanya suatu Tindakan. Hal ini akan menjadi problematika yang serius apabila tidak diselesaikan dengan baik, karnanya perlu informasi yang berimbang seperti review atau ulasan yang baik untuk mempengaruhi persepsi yang buruk konsumen terhadap suatu produk (Sardjono, 2010).

Review secara harifah berarti ulasan yang berisi pendapat atau pemikiran seseorang tentang suatu kualitas, kondisi, kelebihan dan kekurangan produk atau jasa yang telah digunakan. Review atau ulasan sejatinya mempunyai banyak manfaat baik bagi penjual, konsumen, pihak lain tergantung cara penggunannya, apabila kita menggunakan review atau ulasan secara baik dan bijak maka akan 
menghasilkan keuntungan bagi semua pihak. Saat ini konsumen terbiasa melihat review atau ulasan seseorang sebelum melakukan transaksi belanja secara online di aplikasi atau platform e-commerce, untuk memastikan produk atau jasa yang ditawarkan layak atau tidaknya untuk dibeli dikarenakan pengujian produk dilakukan oleh konsumen sendiri melalui cara foto, video, atau tulisan yang kemudian dibagikan kepada konsumen lain dengan cara mengupload hasil review atau ulasan melalui media social yang banyak digunakan masyarakat sehingga dapat dijangkau oleh konsumen secara luas. Di Indonesia sendiri saat ini tidak sedikit masyarakat yang mereview atau mengulas produk/jasa yang ditawarkan, dan karna hal ini lah yang menyebabkan munculnya suatu profesi baru yang bernama influencer. Review atau ulasan dari konsumen langsung berbeda dengan iklan yang dilakukan oleh pelaku usaha sendiri, iklan dari pelaku usaha cenderung dilakukan secara berlebihan karena tidak dilakukan secara jujur sehingga lebih memperlihatkan kelebihan produk dan menyembunyikan kekurangan produk yang menyebabkan tidak berimbangnya informasi yang didapat oleh konsumen, tentu hal ini dilakukan pelaku usaha sebagai media promosi untuk meningkatkan penjualan produk mereka agar laris di masyarakat. Dijaman yang serba modern ini konsumen cenderung lebih membutuhkan banyak informasi yang sesuai dengan kenyataan karena tingginya persaingan usaha, banyaknya jumlah pelaku usaha, beragamnya produk yang ditawarkan, daya beli konsumen yang meningkat, mudahnya akses distribusi produk, teknologi, informasi dan komunikasi yang memungkinkan terbukanya jaringan usaha yang lebih luas dan besar (Peter, 1999). Dalam mereview atau mengulas produk ada etika dan norma yang harus diperhatikan konsumen seperti :

1. Menggunakan kata kata yang sopan dalam menyampaikan pendapat.

2. Tidak menyinggung hal yang bermakna sensitif seperti Pornografi, Ras, Sara dan Kekerasan.

3. Berkata jujur dalam memberikan pendapat.

4. Memberikan saran/kritik yang membangun bagi penjual.

Dengan adanya norma ini berarti konsumen tidak bisa sembarang dalam memberikan pendapatnya atau hasil reviewnya tentang suatu produk di media social, karena kita sebagai manusia yang dianugrahi ilmu pengetahuan alangkah bijak apabila bisa menyampaikan pendapat tanpa menyakiti perasaan orang lain dan menimbulkan masalah baru selain itu, saat ini ditengah ketatnya persaingan usaha baik secara offline atau online ada saja oknum-oknum yang tidak bertanggungjawab memberikan ulasan atau review produk fiktif yang buruk kepada penjual dengan tujuan menjatuhkan rating atau citra penjual di mata konsumen, Tindakan seperti ini lah yang sangat merugikan penjual karna harus memperbaiki citra yang telah rusak dimata konsumen.

Dalam ruang lingkup pemahaman hukum, hukum merupakan suatu peraturan baik tertulis ataupun tidak tertulis yang diciptakan untuk mengatur tingkah laku manusia, perilaku dimasyarakat dengan tujuan mewujudkan rasa keadilan, ketertiban dan keamanan di suatu lingkungan masyarakat, Peraturan hanya dikeluarkan oleh pejabat yang berwenang sesuai dengan tugas pokoknya masing masing, disetiap aturan biasanya terdapat sanksi hukum yang melekat sanksi ini bersifat tegas dan memaksa yang mana apabila kita melanggar peraturan yang ada maka akan diberi sanksi sesuai aturan yang berlaku. Dalam system hukum di Indonesia sendiri terdapat 3 jenis sanksi yang berisi sanksi hukum pidana, sanksi hukum perdata, sanksi hukum administratif (BN, 2009).

Sanksi hukum pidana terdapat 5 jenis sanksi pidana pokok dan 3 jenis sanksi pidana tambahan yakni :

1. Sanksi Pidana Mati : Sanksi pidana mati merupakan sanksi pidana terberat dalam system hukum di Indonesia, hal ini diberarti terdakwa tersebut telah kehilangan hak asasi manusianya yaitu hak untuk hidup karena perbuatan yang telah dilakukannya tidak bisa dimaafkan dan menimbulkan banyak kerugian bagi banyak orang. Banyak terjadi pro kontra di masyarakat tentang sanksi pidana mati ini pihak yang pro dengan kebijakan ini cenderung berpikir bahwa seorang narapidana yang telah melakukan banyak kejahatan dan berdampak luas bagi masyarakat tidak lagi mempunyai hak untuk hidup karna perbuatannya, sedangkan pihak yang menentang sanksi pidana mati mempunyai pandangan tidak seorangpun yang dapat mencabut hak untuk hidup seseorang kecuali tuhan, bahkan bagi negara lain pun ada yang masih menerapkan sanksi pidana ini dan aja juga yang sudah tidak menerapkan sanksi ini.

2. Sanksi Pidana Penjara : Selain Sanksi Pidana Mati terdapat juga sanksi hukum pidana penjara atau kurungan, sanksi penjara mempunyai arti hukuman yang diberikan kepada seorang narapidana berupa kehilangan hak untuk bersosialisasi dengan individu lain secara bebas dan 
menetap di dalam Lembaga pemasyarakatan yang khusus menangani hal ini, sanksi kurungan mempunyai jangka waktu yang berbeda beda tergantung kejahatan yang dilakukan juga putusan hakim.

3. Sanksi Pidana Denda : Selain daripada sanksi pidana mati dan sanksi pidana penjara terdapat juga sanksi pidana denda, sanksi pidana denda mempunyai arti bahwa seseorang yang melakukan kejahatan dihukum dengan cara membayar sejumlah uang kepada pengadilan atau pihak yang dirugikan, sanksi pidana denda merupakan sanksi yang paling ringan diantara sanksi pidana mati atau sanksi pidana penjara. Biasanya sanksi ini diberikan kepada seseorang karna kesalahannya tidak teralu besar atau tidak merugikan banyak orang. Jumlah uang yang dibayar untuk denda berbeda beda setiap orang nya tergantung peraturan, tingkat pelanggaran yang dilakukan. Selain sanksi hukum pidana terdapat juga sanksi hukum perdata yang sesuai dengan ketentuan system hukum di Indonesia.

Adapun jenis jenis putusan hukum perdata dapat berupa :

1. Putusan Constitutif merupakan suatu keputusan yang dikeluarkan oleh pejabat berwenang dalam hal ini hakim pengadilan untuk memutus hubungan hukum lama dan menciptakan hubungan hukum baru antar individu, sebagai contoh : putusan perceraian dalam suatu ikatan perkawinan, selain itu juga terdapat putusan hak asuh anak dalam perkawinan.

2. Putusan Condemnatoir merupakan suatu keputusan yang diberikan hakim kepada pihak yang kalah dalam pengadilan bersifat menghukum untuk memenuhi kewajibannya sesuai dengan tuntutan pihak yang menang, sebagai contoh : putusan hakim dalam sengketa wanprestasi perjanjian hutang piutang.

3. Putusan Declaratoir merupakan suatu putusan yang diberikan oleh hakim yang amarnya membuat suatu kondisi yang sah dalam system hukum, yang berisi penerangan dan penegasan suatu perkara hukum, contohnya adalah putusan sengketa tanah atas penggugat atas kepemilikan yang sah.

Di dalam sistematika hukum sanksi administrasi mempunyai arti sebagai manifestasi kekekuasaan yang bersifat mutlak yang bisa dipergunakan oleh pemerintah pemegang kekuasaan sebagai bentuk reaksi atas ketidakpatuhan terhadap kewajiban yang terdapat dalam aturan hukum yang telah ditetapkan. Berdasarkan definisi yang telah disampaikan ini tampak ada empat unsur sanksi dapat dilihat dari segi sasarannya dalam hukum yaitu sanksi reparatoir merupakan sanksi yang digunakan sebagai bentuk reaksi atas pelanggaran hukum, yang bertujuan untuk mengembalikan kerusakan pada kondisi awal sebelum terjadinya pelanggaran. Sanksi punitif merupakan sanksi admistratif yang digunakan untuk memberikan hukuman berupa pembayaran denda terhadap seseorang. Sanksi regresif merupakan sanksi yang digunakan sebagai reaksi atas pelanggaran terhadap ketentuan hukum yang dibuat oleh pejabat berwenang.

Di indonesia sendiri banyak kita lihat permasalahan tentang review atau mengulas suatu produk dan jasa di berbagai macam media social, tetapi biasanya perkara hukum seperti ini diselesaikan secara kekeluargaan yang lebih mengedepakan mediasi dialog antara penjual dan konsumen langsung sehingga menemukan jalan tengah dan berujung kesepakatan damai antar para pihak, namun bukan berarti tidak ada perkara review atau mengulas produk dan jasa yang tidak bisa diselesaikan dengan mediasi bahkan sampai berujung ke pengadilan, salah satu perkara yang menarik perhatian masyarakat di Indonesia adalah kasus perseteruan artis Kartika putri dengan seorang dokter kecantikan Bernama dr. Richard Lee, perseteruan Panjang ini bermula Ketika artis cantik berumur 30 tahun ini Kartika putri diduga menerima endorse atau promosi produk kecantikan yang mengandung bahan bahan berbahaya yang tidak bagus bagi Kesehatan oleh dr, Richard Lee, tidak terima nama baiknya dicemarkan oleh tuduhan seperti itu artis Kartika putri melaporkan dr. Richard Lee ke pihak berwajib atas dugaan pencemaran nama baik, sebaliknya dr. Richard Lee yang dihubungi pihak berwajib kaget mendengar hal tersebut karena dia tidak merasa tidak pernah menyinggung nama artis Kartika putri, kemudian dr. Richard lee yang turut merasa dirugikan melaporkan balik artis Kartika putri ke polda sumatera selatan. Dalam amar putusan yang dipajang Dokter Richard Lee dalam saluran Youtubenya, Pengadilan Negeri Jakarta pusat menyatakan mengabulkan eksepsi tergugat dan menghukum penggugat untuk membayar biaya perkara sejumlah lebih dari Rp. 900 juta. 


\section{SIMPULAN DAN SARAN}

\section{Simpulan}

Pengaturan hukum bagi kegiatan mereview suatu produk dapat dilihat dalam beberapa pasal yaitu dalam point di pasal 4 Undang-undang Perlindungan Konsumen bahwasannya konsumen berhak didengar keluhan atau pendapatnya atas barang atau jasa yang digunakan, lalu diatur dalam pasal 5 Undang-Undang Perlindungan Konsumen yaitu kewajiban konsumen untuk memperkecil kemungkinan timbulnya kerugian dan salah paham. Selain itu masyarakat dalam mereview suatu produk juga diatur melalui pasal 27 ayat (3) Undang-Undang Nomor 19 Tahun 2016 tentang perubahan atas Undang-undang Nomor 11 Tahun 2008 tentang Informasi dan Transaksi Elektronik yang dimana mengatur mengenai pencemaran nama baik untuk melindungi produsen atau pemilik produk dari tuduhan atau review yang bertujuan untuk menjatuhkan nama baik dari brand atau suatu produk.

\section{Saran}

Sesuai dengan hasil penelitian ini, maka ada beberapa saran yang perlu disampaikan yaitu untuk menjamin hak asasi manusia dari konsumen yakni kebebasan menyuarakan pendapat, kritik dan saran maka pemerintah dalam hal ini sebagai pihak yang memegang kekuasaan dalam membuat kebijakan dan menjalankan kebijakan perlu kiranya memberikan perlindungan hukum bagi konsumen yang dijamin oleh konstitusi di negara Republik Indonesia ini, selain itu perlu di pertegas Kembali aturan ini bagi oknum-oknum yang tidak bertanggung jawab ingin menjatuhkan pelaku usaha lain dalam persaingan usaha ini.

\section{DAFTAR PUSTAKA}

Atmadja, I Dewa Gede Budiartha, I. N. P. (2019). Sistematika Filsafat Hukum. Setara Press, Malang. BN, A. (2009). Perkembangan Sistem Pemidanaan di Indonesia. Raja Makmur, Semarang.

Fajar, M., \& Achmad, Y. (2010). Dualisme Penelitian Hukum Normatif dan Empiris. Grafindo utama, Yogyakarta.

Hadiyati, Suroto, B., \& Fatkhurahman. (2018). Evaluasi Pelatihan Menilai Berita Palsu atau "Hoax" Pada Kelompok Arisan Dosen Perempuan. Diklat Review: Jurnal Manajemen Pendidikan Dan Pelatihan, 2(2), 106-112.

Ilmiyah, K., \& Krishernawan, I. (2020). Pengaruh Ulasan Produk, Kemudahan, Kepercayaan, dan Harga Terhadap Keputusan Pembelian Pada Marketplace Shopee di Mojokerto. Maker: Jurnal Manajemen, 6(1), 31-42.

Juditha, C. (2018). Interaksi Komunikasi Hoax di Media Sosial serta Antisipasinya. Jurnal Pekommas, 3(1), 31-44.

Peter, D. (1999). Hak-Hak Asasi Manusia Sebuah Bunga Rampai. Yayasan Obor Indonesia, Jakarta.

Rizaldi, M. (2015). Perkara Pencemaran Nama Baik melalui Media Internet. Masyarakat Pemantau Peradilan Indonesia Fakultas Hukum Universitas Indonesia (MaPPI - FHUI).

Sardjono, A. (2010). Hak Kekayaan Intelektual dan Pengetahuan Tradisional. Alumni, Bandung.

Sutedi, A. (2009). Hak Kekayaan Intelektual. Citra Aditya Bakti, Bandung. 